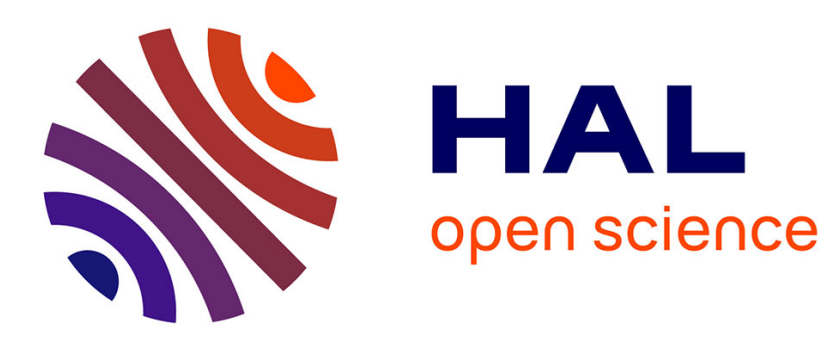

\title{
Clostridial whole cell and enzyme systems for hydrogen production: current state and perspectives
}

\author{
Amel Latifi, Luisana Avilan, Myriam Brugna
}

\section{To cite this version:}

Amel Latifi, Luisana Avilan, Myriam Brugna. Clostridial whole cell and enzyme systems for hydrogen production: current state and perspectives. Applied Microbiology and Biotechnology, 2019, 10.1007/s00253-018-9514-3 . hal-01928533

\section{HAL Id: hal-01928533 \\ https://hal-amu.archives-ouvertes.fr/hal-01928533}

Submitted on 20 Nov 2018

HAL is a multi-disciplinary open access archive for the deposit and dissemination of scientific research documents, whether they are published or not. The documents may come from teaching and research institutions in France or abroad, or from public or private research centers.
L'archive ouverte pluridisciplinaire HAL, est destinée au dépôt et à la diffusion de documents scientifiques de niveau recherche, publiés ou non, émanant des établissements d'enseignement et de recherche français ou étrangers, des laboratoires publics ou privés.

\section{(c)(1)}

Distributed under a Creative Commons Attribution| 4.0 International License 
archives-ouvertes

\title{
Clostridial whole cell and enzyme systems for hydrogen production: current state and perspectives
}

\author{
Amel Latifi, Luisana Avilan, Myriam Brugna
}

\section{To cite this version:}

Amel Latifi, Luisana Avilan, Myriam Brugna. Clostridial whole cell and enzyme systems for hydrogen production: current state and perspectives. Applied Microbiology and Biotechnology, Springer Verlag, $2018,<10.1007 /$ s00253-018-9514-3>. <hal-01928533>

\section{HAL Id: hal-01928533 \\ https://hal-amu.archives-ouvertes.fr/hal-01928533}

Submitted on 20 Nov 2018

HAL is a multi-disciplinary open access archive for the deposit and dissemination of scientific research documents, whether they are published or not. The documents may come from teaching and research institutions in France or abroad, or from public or private research centers.
L'archive ouverte pluridisciplinaire HAL, est destinée au dépôt et à la diffusion de documents scientifiques de niveau recherche, publiés ou non, émanant des établissements d'enseignement et de recherche français ou étrangers, des laboratoires publics ou privés. 


\title{
Clostridial whole cell and enzyme systems for
}

\section{hydrogen production: current state and perspectives}

\author{
Amel Latifi $^{a, *}$, Luisana Avilan ${ }^{\mathrm{b}}$, Myriam Brugna ${ }^{\mathrm{b}}$
}

a: Aix-Marseille Univ, CNRS, LCB, Laboratoire de Chimie Bactérienne, Marseille, France

b: Aix Marseille Univ, CNRS, BIP, Bioénergétique et Ingénierie des Protéines, Marseille, France

*:latifi@imm.cnrs.fr 


\begin{abstract}
Strictly anaerobic bacteria of the Clostridium genus have attracted great interest as potential cell factories for molecular hydrogen production purposes. In addition to being a useful approach to this process, dark fermentation has the advantage of using the degradation of cheap agricultural residues and industrial wastes for molecular hydrogen production. However, many improvements are still required before large-scale hydrogen production from clostridial metabolism is possible. Here we review the literature on the basic biological processes involved in clostridial hydrogen production, and present the main advances obtained so far in order to enhance the hydrogen productivity, as well as suggesting some possible future prospects.
\end{abstract}

\title{
Key words
}

Clostridia, Fermentation, Hydrogen production, Hydrogenase, Metabolic engineering.

\section{Introduction}

The use of molecular hydrogen $\left(\mathrm{H}_{2}\right)$ as a possible alternative to the dwindling supplies of fossil fuels available is one of the most promising strategies being investigated today. In addition to providing a rich source of energy, $\mathrm{H}_{2}$ can be produced enzymatically, which means that it is a clean fuel which should be extremely useful in a large range of energy sectors (Das and Veziroglu 2008). Biological $\mathrm{H}_{2}$ production by some microorganisms involves two classes of enzymes: hydrogenases $\left(\mathrm{H}_{2}\right.$ ases $)$ and nitrogenases. An overview of the progress achieved and the main challenges to be met in this field is available (Gupta et al. 2013). $\mathrm{H}_{2}$ ases are the most efficient enzymes known for biological $\mathrm{H}_{2}$ production. They are structurally diverse enzymes which catalyze the reversible oxidation of $\mathrm{H}_{2}$ into protons and electrons using various electron acceptors and donors. In heterotrophic microorganisms, they are involved in 
the anaerobic conversion of organic substances. This process, known as dark fermentation, has attracted considerable interest in recent years since it can be associated to the recycling of organic wastes. Among the various bacteria able to produce $\mathrm{H}_{2}$ which have been identified so far (including Enterobacter sp, Bacillus sp, Klebsiella sp.), Clostridia are particularly promising candidates because of their comparatively high $\mathrm{H}_{2}$ production efficiency. In addition to $\mathrm{H}_{2}$, these obligate anaerobes produce several other substances of industrial interest, such as lactate, butyrate, acetate, ethanol and butanol. Several aspects of $\mathrm{H}_{2}$ production by Clostridia have been intensively studied during the past two decades, and some particularly noteworthy findings have been obtained as regards the structure of $\mathrm{H}_{2}$ ases and the mechanisms in which they are involved (Reviewed in (Calusinska et al. 2010)). Here we present a short review of $\mathrm{H}_{2}$ ases, focusing in particular on those which are involved in $\mathrm{H}_{2}$ fermentative production, and discuss the current state of the art as regards $\mathrm{H}_{2}$ production using Clostridia in the form of whole cells or enzymes. The contribution of metabolic engineering to enhance fermentative $\mathrm{H}_{2}$ production methods is discussed and some possibilities for future improvements are suggested.

\section{Clostridial hydrogenases involved in dark fermentation}

$\mathrm{H}_{2}$ ases can be classified in three classes, depending on the nature of their active-site metal center: Fe-, NiFe or FeFe-hydrogenases, which are phylogenetically unrelated (Vignais and Billoud 2007; Vignais et al. 2001). NiFe and FeFe families have in common (i) the presence

57 of cyanide $\left(\mathrm{CN}^{-}\right)$and carbon monoxide $(\mathrm{CO})$ ligands coordinating the iron ions at the active site, (ii) FeS clusters forming an electron transfer chain between the active site and electron donors or acceptors at the surface of the enzyme and (iii) gas transfer channels allowing gases $\left(\mathrm{H}_{2}\right.$ as well as inhibitors $\mathrm{O}_{2}$ and $\mathrm{CO}$ ) to diffuse towards or from the buried active site (Cohen et al. 2005; Fontecilla-Camps et al. 2007; Leroux et al. 2008; Montet et al. 1997; Nicolet et al. 1999; Peters et al. 2015). The maturation of $\mathrm{NiFe}-\mathrm{H}_{2}$ ases is a complex process in which the 
biosynthesis and insertion of the $\mathrm{NiFe}$ catalytic center require the products of 6 hyp genes (Lacasse and Zamble 2016). In comparison, the maturation of [FeFe]- $\mathrm{H}_{2}$ ases is more simple; it involves only three accessory proteins for the assembly of the $2 \mathrm{Fe}$ subcluster of the active site: an FeS cluster-binding GTP-ase HydF, and two radical SAM (S-adenosyl-L-methionine) enzymes, HydE and HydG (Broderick et al. 2014; Peters et al. 2015; Shepard et al. 2014).

Most of the studies performed so far on fermentative $\mathrm{H}_{2}$ production by Clostridia have focused on members of the genus Clostridium and on the monomeric $\mathrm{FeFe}-\mathrm{H}_{2}$ ase. The prototypes of this enzyme are $\mathrm{CpI}$ from $C$. pasteurianum and $\mathrm{CaI}$ from $C$. acetobutylicum. The $\mathrm{H}_{2}$ ases in Clostridia are not restricted to this class, since the sequencing of the genome of many strains has shown the presence of genes putatively encoding a wide range of $\mathrm{NiFe}$ - and FeFe- $\mathrm{H}_{2}$ ases (Calusinska et al. 2010; Greening et al. 2016; Poudel et al. 2016). The NiFe$\mathrm{H}_{2}$ ases produced by members of the genus Clostridium belong to groups 1 and 4 of $\mathrm{NiFe}-$ $\mathrm{H}_{2}$ ases in the system of classification by Vignais et al. in 2001 (Calusinska et al. 2010; Vignais et al. 2001). The physiological role of the Group 1 enzymes in Clostridium has not yet been elucidated, nor has that of the Group 4 enzymes, which include membrane-associated $\mathrm{H}_{2}$-evolving respiratory NiFe-enzymes (Calusinska et al. 2010; Vignais et al. 2001).

FeFe- $\mathrm{H}_{2}$ ases occur in anaerobic bacteria such as Firmicutes and Thermotogae and some lower eukaryotes (Greening et al. 2016; Poudel et al. 2016). They are highly efficient $\mathrm{H}_{2}$-producing enzymes and show higher catalytic activity for $\mathrm{H}_{2}$ evolution than NiFe-enzymes (Adams 1990; Frey 2002). Their catalytic site, which is called the H-cluster, consists of a single [4Fe4S] cluster ligated by four cysteine residues linked to a unique organometallic diiron subcluster (Nicolet et al. 1999; Peters et al. 1998). In addition to the catalytic domain containing three evolutionarily conserved binding motifs for the H-cluster (Vignais et al. 2001), some additional domains with accessory clusters can be present, conferring a modular organization on FeFe- $\mathrm{H}_{2}$ ases (Calusinska et al. 2010; Fontecilla-Camps et al. 2007; Poudel et 
al. 2016; Schwartz et al. 2013). The most thoroughly studied $\mathrm{H}_{2}$ ase from Clostridia is the monomeric FeFe enzyme which occurs in some species of the genus Clostridium. The monomeric cytoplasmic CpI enzyme from C. pasteurianum was the first $\mathrm{H}_{2}$ ase to be characterized, and the first of which the three-dimensional structure has been solved (Peters et al. 1998). CpI is involved in the recycling of the reduced ferredoxin produced during the dark fermentation process (see below) by producing $\mathrm{H}_{2}$ via a proton reduction step (Therien et al. 2017). Homologs of CpI are present in some Clostridium species (Calusinska et al. 2010) such as C. acetobutylicum, in which Cal produces $\mathrm{H}_{2}$ from reduced ferredoxin or flavodoxin (Demuez et al. 2007).

The model enzymes $\mathrm{CaI}$ and $\mathrm{CpI}$ have been studied at the molecular level with a view to improving our knowledge of the catalytic and structural properties of $\mathrm{FeFe}-\mathrm{H}_{2}$ ases. In addition to the H-cluster, these enzymes contain, a Y-shaped electron transfer chain consisting of four accessory FeS clusters, three 4Fe4S clusters and one $2 \mathrm{Fe} 2 \mathrm{~S}$ cluster (Peters et al. 1998). Although it has been established that these accessory clusters contribute importantly to the activity of the enzyme, their exact role has not yet been determined (Artz et al. 2017; Gauquelin et al. 2018). FeFe- $\mathrm{H}_{2}$ ases are highly $\mathrm{O}_{2}$-sensitive enzymes, which considerably limits their potential for use in biotechnological systems for $\mathrm{H}_{2}$ production purposes. CaI and $\mathrm{CpI}$, along with the $\mathrm{FeFe}-\mathrm{H}_{2}$ ase $\mathrm{HydA}$ from Chlamydomonas reinhardtii, are the most suitable model enzymes for studying the mechanism involved in $\mathrm{O}_{2}$ inhibition (Koo et al. 2016; Kubas et al. 2017; Noth et al. 2015; Orain et al. 2015). In particular, the molecular mechanism of $\mathrm{O}_{2}$ diffusion within the enzyme and its reactions at the active site have been studied by combining several approaches such as electrochemistry, site-directed mutagenesis and molecular dynamics approaches (Kubas et al. 2017; Orain et al. 2015). A better understanding of this mechanism should make it possible to design recombinant enzymes which are resistant to $\mathrm{O}_{2}$. In addition to $\mathrm{CpI}$, two other genes of $C$. pasteurianum encode 
monomeric FeFe-hydrogenases, CpII and CpIII (Rotta et al. 2015; Therien et al. 2017). CpIII still remains to be characterized, whereas CpII has been analyzed biochemically. This enzyme shows a lower $\mathrm{H}_{2}$ production rate than $\mathrm{CpI}$ but oxidizes $\mathrm{H}_{2}$ (Adams 1990). It was recently established that $\mathrm{CpII}$ is an uptake $\mathrm{H}_{2}$ ase that captures electrons from the $\mathrm{H}_{2}$ produced during the nitrogen fixation process (Therien et al. 2017).

In addition to the monomeric $\mathrm{FeFe}$ enzymes, multimeric $\mathrm{FeFe}-\mathrm{H}_{2}$ ases have been identified in Clostridia. These trimeric or tetrameric flavo-enzymes have been found to bifurcate electrons. The flavin-based electron-bifurcation process, which was first discovered in 2008 (Li et al. 2008), was proposed to be a third mode of energy conservation in microorganisms in addition to electron transport phosphorylation and substrate level phosphorylation (Buckel and Thauer 2013). Electron-bifurcating enzymes couple an exergonic redox reaction to an endergonic one, and the simultaneous reduction or oxidation of two electron acceptors or donors occurs (Buckel and Thauer 2018a; Buckel and Thauer 2018b). Five bifurcating $\mathrm{H}_{2}$ ases from strictly anaerobic bacteria have been described up to now (Kpebe et al. 2018; Schuchmann and Muller 2012; Schut and Adams 2009; Wang et al. 2013b; Zheng et al. 2014). Three of them belong to the Clostridia (Acetobacterium woodii, Moorella thermoacetica and Ruminococcus albus). Electron-bifurcating $\mathrm{H}_{2}$ ases, which have a similar conserved $\mathrm{H}_{2}$ activation subunit to that of the $\mathrm{CpI}$ of $C$. pasteurianum, are unique in that they catalyze the oxidation of $\mathrm{H}_{2}$ by reducing ferredoxin and $\mathrm{NAD}^{+}$simultaneously. They are also electron confurcating enzymes, since they can catalyze the coupled reduction of protons to $\mathrm{H}_{2}$ via the oxidation of reduced ferredoxin and NADH. In C. autoethanogenum, an NADP-specific electron-bifurcating FeFe$\mathrm{H}_{2}$ ase forms a complex with a formate dehydrogenase (Wang et al. 2013a).

\section{Fermentative $\mathrm{H}_{2}$ production in Clostridia}


At least 33 clostridial species have been tested so far as possible means of $\mathrm{H}_{2}$ production with a large range of substrates and growth techniques (Rittmann and Herwig 2012). In the dark fermentation process, Clostridia produce pyruvate, ATP and NADH by oxidizing organic molecules, mainly those consisting of sugars, via a process of glycolysis (Figure 1). Pyruvate is subsequently converted by pyruvate:ferredoxin (Fd) oxidoreductase (PFOR) into acetyl$\mathrm{CoA}$ and $\mathrm{CO}_{2}$, yielding reduced Fd. Under special conditions, the NADH thus formed can be oxidized and the Fd reduced by NADH:ferredoxin oxidoreductase (NFOR) (Vardar-Schara et al. 2008). This reduced Fd is used by electron-bifurcating or monomeric Fd-dependent FeFe$\mathrm{H}_{2}$ ases to reduce protons, yielding $\mathrm{H}_{2}$. The acetyl-CoA formed follows several metabolic pathways during fermentation, mainly yielding acetate or butyrate. The butyrate pathway competes with $\mathrm{H}_{2}$ production since it involves the use of NADH. Since the regeneration of $\mathrm{NAD}^{+}$is required for glycolysis to occur, several other fermentation products such as ethanol and butanol can be formed, and the $\mathrm{H}_{2}$ production yield can vary depending on the pathway taken. Theoretically, 12 moles of $\mathrm{H}_{2}$ can be produced per mole of glucose (Figure 1). However, this theoretical yield is never actually reached in any fermentative organisms. The maximum yield possible with Clostridia (and strict anaerobes in general) is 4 moles of $\mathrm{H}_{2}$ per mole of glucose when acetone or acetate are produced; this maximum, which is called the Thauer limit (Thauer et al. 1977), is never reached in practice since the thermodynamic conditions for the conversion of NADH into $\mathrm{H}_{2}$ are not favorable. To enhance the $\mathrm{H}_{2}$ productivity, the challenge is therefore to find means of circumventing all the latter obstacles $\left(\mathrm{H}_{2}\right.$ consumption, competitive pathways for reductant supply, and the theoretical limits of the pathway).

A large panel of physicochemical dark fermentation conditions have been tested with Clostridium species, with a view to increasing the $\mathrm{H}_{2}$-production yield (some examples are provided in Table I). Clostridium species are able to use a wide range of substrates, including 
pure carbohydrates (i.e., glucose/sucrose) and carbohydrate enriched substrates, which have been the most widely tested. Abundant lignocellulosic biomass, cellulose and hemicelluloses from organic waste and carbohydrate-rich waste from the agro-industry are also suitable substrates for $\mathrm{H}_{2}$ production. This process therefore decreases the environmental impact of waste by harnessing it to biofuel production. To ensure the efficient use of these complex substrates, two steps have to be optimized, namely converting the substrate into sugar units that can be metabolized, and inducing the uptake of these forms through the membrane (Figure 1). It has been established that in several Clostridium species such as $C$. acetobutylicum, a phosphoenolpyruvate (PEP)-dependent phosphotransferase system (PTS) mechanism is responsible for the uptake of sugars (Tangney and Mitchell 2007).

Several Clostridium species and other anaerobic microorganisms comprise large extracellular enzymatic entities called cellulosomes which are required for the degradation of complex polysaccharides (Bayer et al. 2004). In these multi-enzyme complexes, several degradative enzymes such as cellulases and hemicellulases (Sabathe et al. 2002) degrade cellulosic substrates. Some of the Clostridium species, such as C. acetobutylicum, with cellulolytic activity tested do not hydrolyze crystalline cellulose and are not able to grow on this substrate as the sole source of carbon (Lee et al. 1985). However, Clostridium thermocellum, and other thermophilic species, are able to use cellulose as carbon source and offer a high potential to produce $\mathrm{H}_{2}$ by cellulosic material such as delignified wood fibers (Levin et al. 2006). A bioinformatics analysis of $C$. thermocellum 27405 genome sequence has suggested that $\mathrm{H}_{2}$ synthesis in this bacterium would involve either a Ferredoxin ( $\mathrm{Fd}$ )-dependent $\mathrm{NiFe}_{2}$ ase, or a NAD(P)H-dependent Fe- $\mathrm{H}_{2}$ ase (Carere et al. 2008). Further efforts are required in this field to tackle limiting obstacles to the effective use of Clostridia for $\mathrm{H}_{2}$ production from lignocellulosic waste biomass. 
In addition to the type of substrate, physical parameters (such as $\mathrm{pH}$, agitation, temperature), the operating mode (the batch, continuous or semi-continuous process) and reactor design are other essential factors contributing to $\mathrm{H}_{2}$ production, as reviewed in (Kothari et al. 2017; Show et al. 2008). It is necessary, for example, to maintain a low partial $\mathrm{H}_{2}$ pressure to prevent inhibition by the product (Mizuno et al. 2000). The use of immobilized microorganisms (by adsorption, encapsulation or entrapment in a matrix), contrary to cell suspensions, has been found to improve $\mathrm{H}_{2}$ production by maintaining a high biomass concentration, and thus ensuring the stability of the system (Banu et al. 2018; Kumar et al. 2016). Using an immobilized Thermotoga, the $\mathrm{H}_{2}$ production rate was found to reach $3.3 \mathrm{~mol}$ $\mathrm{H}_{2} / \mathrm{mol}$ glucose, which is near the expected Thauer limit of these organisms. Immobilized Clostridium species have also been found to yield higher $\mathrm{H}_{2}$ production rates than free suspensions (2.91 $\mathrm{mol} \mathrm{H}_{2} / \mathrm{mol}$ glucose versus $1.97 \mathrm{~mol} \mathrm{H}_{2} / \mathrm{mol}$ glucose) (Nomura et al. 2014; Seelert et al. 2015; Zhao et al. 2011) (Table 1).

Although Clostridium species are relatively high $\mathrm{H}_{2}$ producers, mixed cultures can give better results with the fermentative procedure. One example of these mixed cultures is the sludge originating from various sources, which, in addition to strictly anaerobic microorganisms, also contains facultative anaerobes consuming $\mathrm{O}_{2}$. This oxygen consumption benefits to Clostridium whose growth would otherwise be inhibited due to its $\mathrm{O}_{2}$-sensitivity. A combination of C. butyricum and Enterobacter aerogenes produced a yield of $2 \mathrm{~mol} \mathrm{H}_{2} / \mathrm{mol}$ glucose using an industrial starch waste substrate from potato and corn (Yokoi et al. 2001). In addition, the interactions between microorganisms in mixed cultures can result in beneficial physical interactions and a distribution of nutrients improving the metabolic fluxes in the cells, as observed, for example, in mixed cultures of $C$. acetobutylicum and Desulfovibrio vulgaris Hildenborough, a sulfate reducing bacterium, which considerably increased the $\mathrm{H}_{2}$ production rate (Benomar et al. 2015). 
One particularly interesting mixed culture process which can be used for $\mathrm{H}_{2}$ production, based on a combination between dark and photofermentation methods, can theoretically give a maximum yield of $12 \mathrm{~mol} \mathrm{H}_{2}$ per mol of glucose in two steps: the first dark fermentation step yields $\mathrm{H}_{2}$, organic compounds and $\mathrm{CO}_{2}$, and these organic compounds are used in the second step by photofermenting bacteria, using captured light to enhance the levels of $\mathrm{H}_{2}$ and $\mathrm{CO}_{2}$ produced. In another fermentative process, a co-culture of $C$. butyricum and the photosynthetic bacterium Rhodopseudomonas palustris yielded up to $6.4 \mathrm{~mol} \mathrm{H}_{2} / \mathrm{mol}$ hexose (Hitit et al. 2017; Lo et al. 2010). Combining all three types of metabolism can be another advantageous strategy. A co-culture of $C$. butyricum and E. aerogenes, which was performed in a sequential fermentative process with Rhodobacter sp. yielded $7.2 \mathrm{~mol} \mathrm{H}_{2} / \mathrm{mol}$ glucose (Yokoi et al. 2001) (Table 1).

Although the use of Clostridium species for the production of $\mathrm{H}_{2}$ in dark fermentation is very promising, other species, specifically hyperthermophiles, have shown higher yields in the conversion of substrates in comparison to many mesophilic Clostridium species. However, the volumetric productivity in hyperthermophiles is lower (Rittmann and Herwig 2012). One of the factors that explain the high $\mathrm{H}_{2}$ production yield of these organisms is related to the thermodynamic of enzymatic reactions; the change in Gibbs free energy of the overall reaction from glucose to acetate and $\mathrm{H}_{2}$ makes the reaction more favorable (Hallenbeck 2005). High temperature also provides other advantages to the $\mathrm{H}_{2}$ production process such as lower risk of contamination and lower viscosity. In addition, specific metabolism characteristics of the hyperthermophiles favor $\mathrm{H}_{2}$ production (Verhaart et al. 2010). High yields of $\mathrm{H}_{2}$ production (up to $3.8 \mathrm{~mol} \mathrm{H}_{2} / \mathrm{mol}$ hexose) have been obtained with the thermophile Thermoanaerobacterium spp., and the hyperthermophiles Thermotoga spp. and Pyrococcus furiosus (Verhaart et al. 2010). Mixed cultures of these hyperthermophiles microorganisms with Rhodobacter species also can produce high yields. A yield of 6.85 mol 
$\mathrm{H}_{2} /$ mol hexose was obtained in a mixed culture containing the hyperthermophile Caldicellulosiruptor saccharolyticus and Rhodobacter capsulatus (Ozgur et al. 2010).

\section{Metabolic engineering of clostridial strains to promote $\mathrm{H}_{2}$ production}

In the context of $\mathrm{H}_{2}$ production using dark fermentation, metabolic engineering methods consisting in modifying enzymes or metabolic pathways have been used to overcome limiting factors in order to enhance the $\mathrm{H}_{2}$ production yield. Since clostridial genomes are rather difficult to modify, relatively few studies have been conducted on these lines in comparison with those on other heterotrophic $\mathrm{H}_{2}$ producing organisms. However, recent progress in the genetic engineering of Clostridia has significantly improved this situation during the past decade. The genetic and synthetic biology toolbox available for use with Clostridia has been summarized in (Joseph et al. 2018). Recent efforts to improve the $\mathrm{H}_{2}$ yield have focused on the two main factors limiting the production pathway: (i) increasing and broaden the variety of carbohydrates that can be incorporated and used as carbon source for the growth (red dots in Figure 1); (ii) and enhancing the yield and/or the rate of $\mathrm{H}_{2}$ production from pyruvate. The first line of investigation, which focuses mainly on the growth on lignocellulosic substrates, involves the overexpression of hemicellulases, cellulases and lignases as means of enhancing substrate digestion and glucose availability. This strategy is not specific to $\mathrm{H}_{2}$, but enhances the amounts of all the fermentation products released, including ethanol, butanol and acetate; the latest progress made on these lines has been summarized in (Chandel et al. 2012; Olson et al. 2012; Thomas et al. 2014). The transport system for sugars in Clostridium could also be object of manipulation as a strategy to optimize the uptake of substrates (Mitchell 2016). In a recent study, Jiang et al (Jiang et al. 2017) reported that the over-expression of the inulinase gene from Paenibacilluspolymyxa in C. tyrobutyricum resulted in relatively high levels of $\mathrm{H}_{2}$ production from the fermentation of the inulin-rich Jerusalem artichoke. Another improvement strategy consists in broadening the panel of substrates used for the bacterial 
growth. In this context, the cloning and expression of xylose-utilization genes of Thermoanaerobacter ethanolicus in Clostridium thermocellum DSM 1313 allowed the recombinant strain obtained to co-ferment sugars that can be derived from cellulose and hemicellulose. The production of $\mathrm{H}_{2}$ was twice higher when bacteria grew on cellulose and xylose as compared to cellulose alone (Xiong et al. 2018). This study represents an encouraging step towards the use of plant biomass for the synthesis of valuable products. All in all, the studies cited above confirm that combining metabolic engineering and use of alternative substrates is a promising strategy.

Once the sugar sources have been transformed into pyruvate, $\mathrm{H}_{2}$-enhancement strategies are applied, consisting either of inhibiting competitive pathways or improving the $\mathrm{H}_{2}$-producing branch of the fermentative metabolism (yellow and blue dots, respectively, in Figure 1). In $C$. tyrobutyricum, inhibiting the acetate pathway by generating a deletion mutant of the acetate kinase gene (ack) resulted in a 2-fold increase in the $\mathrm{H}_{2}$ production level on glucose (Liu et al. 2006). Disrupting the ethanol pathway by inactivating the gene encoding the bifunctional aldehyde-alcohol-dehydrogenase was also tested with a view to directing larger amounts of NADH to $\mathrm{H}_{2}$ ases, but the recombinant strain did not show an enhanced level of $\mathrm{H}_{2}$ production as expected, probably because the mutation favored the lactate pathway. Adding sodium acetate to stimulate lactate utilization induced a $20 \%$ increase in the $\mathrm{H}_{2}$ production in this genetic background (Cai et al. 2013). Previous results suggested that inhibiting the butyrate pathway was not a useful approach for $\mathrm{H}_{2}$-enhancement in this strain, although positive results were expected in view of the theoretical models, since this strategy may also increase the amount of NADH available for the $\mathrm{H}_{2}$ pathway (Cai et al. 2011). As regards the strategies that have specifically addressed the $\mathrm{H}_{2}$ pathway, an RNA antisense approach to downregulating the expression of the uptake hydrogenase resulted in a 3.1 fold increase in the amount of $\mathrm{H}_{2}$ accumulated by $C$. saccharoperbutylacetonicum (Nakayama et al. 2008). 
Homologous overexpression of the $\mathrm{FeFe}-\mathrm{H}_{2}$ ase encoding gene hydA has been found to enhance $\mathrm{H}_{2}$-productivity in $C$. paraputrificum and $C$. tyrobutyricum 1.7 - and 1.5-fold, respectively (Hye et al. 2010; Morimoto et al. 2005). Interestingly, this approach did not affect the $\mathrm{H}_{2}$ productivity in $C$. acetobutylicum, and the authors concluded that the CaI enzyme concentration must not be a limiting factor in this strain (Klein et al. 2010). All in all, the data obtained in these studies suggest that the overall amount of $\mathrm{H}_{2}$ produced depends largely on the genetic background used, and that the predicted patterns are not always conclusive.

\section{Use of clostridial hydrogenases in heterologous systems}

In addition to investigating $\mathrm{H}_{2}$ production from Clostridia cultures, the heterologous expression of clostridial $\mathrm{H}_{2}$ ases has been investigated in both heterotrophic and autotrophic micro-organisms. Using Escherichia coli as a host for the production and purification of $\mathrm{H}_{2}$ ases has largely contributed to our knowledge on structure and function of these enzymes and on the mechanism of their maturation. Here we will focus on studies on the heterologous expression of clostridial genes as a means of enhancing $\mathrm{H}_{2}$ production from E. coli. The powerful effects of the genetic engineering of $E$. coli have been illustrated in a study in which the authors succeeded in building a metabolic pathway yielding significant amounts of $\mathrm{H}_{2}$ from pyruvate fermentation. The authors of the latter study co-expressed six genes encoding the following proteins: the pyruvate:ferredoxin-oxidoreductase from $E$. coli, the $C$. pasteurianum [4Fe4S]-ferredoxin, and the C. acetobutylicum monomeric $\mathrm{FeFe}-\mathrm{H}_{2}$ ase $\mathrm{CaI}$ and the three enzymes involved in its maturation (HydE, HydF and HydG). In addition, the deletion of the iscR gene encoding the repressor of the $[\mathrm{FeS}]$ cluster biogenesis operon resulted in 2-fold increase in the $\mathrm{H}_{2}$ production yield (Akhtar and Jones 2009). Although the use of heterotrophic hosts growing on glucose is not economically sustainable for $\mathrm{H}_{2}$ production, synthetic pathways such as that described in this study can pave the way to their 
use in microorganisms which are able to degrade and metabolize complex polysaccharides. Rewiring solar energy to activate $\mathrm{H}_{2}$ ase is another attractive $\mathrm{H}_{2}$-bioproduction strategy (Dubini and Ghirardi 2015; Khanna and Lindblad 2015; Martin and Frymier 2017). In this framework, the sensitivity of these enzymes to $\mathrm{O}_{2}$ is one of the main obstacles to be overcome. $\mathrm{CaI} \mathrm{H}_{2}$ ase from $C$. acetobutylicum has been produced in the unicellular cyanobacterium Synechococcus elongatus and the recombinant strain produced 500-fold more $\mathrm{H}_{2}$ than the parental strain under conditions where the activity of the $\mathrm{O}_{2}$-producing photosystem was inhibited (Ducat et al. 2011). We recently succeeded in producing the same enzyme as in the latter study in the heterocysts of the filamentous nitrogen-fixing cyanobacterium Nostoc PCC 7120. Contrary to what was expected to occur, these micro-oxic cells naturally hosting the $\mathrm{O}_{2}$-sensitive nitrogenase turned out not to be appropriate for producing $\mathrm{CaI}$. However, increasing the anaerobiosis in the heterocyst by overexpressing a cyanoglobin was found to be an effective strategy, since $\mathrm{H}_{2}$ production could be achieved under conditions where the process of photosynthesis was active (Avilan et al. 2018). In addition to looking for the most biotechnologically suitable host for clostridial $\mathrm{H}_{2}$ ases, direct evolution approaches can be expected in the future to enhance the yield of $\mathrm{H}_{2}$ produced by the recombinant strains. As a proof of concept, a selected chimeric $\mathrm{FeFe}-\mathrm{H}_{2}$ ase which evolved from two clostridial sequences produced and purified from E. coli showed a $400 \%$-fold increase in the $\mathrm{H}_{2}$ ase in vitro activity in comparison with the parental sequence (Plummer et al. 2016). In a recent study, a directed mutagenesis of the $\mathrm{FeFe} \mathrm{H}_{2}$ ase $\mathrm{Cpl}$ from Clostridium pasteurianum has showed that a single Cysteine substitution near the proximal delivery center significantly increased the tolerance to $\mathrm{O}_{2}$ without lowering the amount of $\mathrm{H}_{2}$ produced (Koo et al. 2016). Moreover, the $\mathrm{O}_{2}$-tolerant enzymes obtained have been shown to be active in an in vitro system using light and a cyanobacterial photosystem 1 (Koo et al. 2016). This result 
suggests that these engineered $\mathrm{O}_{2}$-tolerant $\mathrm{H}_{2}$ ases can be implemented in photosynthetic organisms to take advantage of solar energy for $\mathrm{H}_{2}$ production.

\section{Conclusion and perspectives}

Fermentative $\mathrm{H}_{2}$ production processes have several advantages over other processes. The growth rate of fermentative organisms is relatively fast and a large range of carbon sources such as organic compounds, wastes, and cellulosic compounds can be used. They therefore have considerable potential for use in industrial applications. However, before this aim can be achieved, further research is required to deal with all the limiting factors reducing $\mathrm{H}_{2}$ productivity. Future efforts will have to focus on improving the ability of the strains to degrade waste and complex polysaccharide substrates, and sugar uptake is another point which needs to be investigated more closely. The latest progress made in the genetic engineering of Clostridia should lead to the development of more successful means of shutting down competitive pathways that rely on the same reductants than $\mathrm{H}_{2}$. Gene shuffling and direct evolutionary approaches need to be further developed in order to enhance the activity of $\mathrm{H}_{2}$ ases and/or limit their sensitivity to $\mathrm{O}_{2}$. These approaches are of great potential interest not only from the point of view of fermentative $\mathrm{H}_{2}$ production but also as regards the use of clostridial enzymes in photosynthetic processes.

One of the more negative aspects of dark fermentation is the production of $\mathrm{CO}_{2}$, a greenhouse gas. The possibility of coupling $\mathrm{H}_{2}$ production from Clostridia to $\mathrm{CO}_{2}$-consuming processes using algae or cyanobacteria for either the photosynthetic production of $\mathrm{H}_{2}$ or other industrial applications would be worth investigating. Generally speaking, it would certainly be of great interest to find ways of using the metabolic and genetic interactions liable to occur in microbial communities: screening natural microbial communities or engineering specific 
microbial ecosystems should yield useful methods of boosting $\mathrm{H}_{2}$ production by fermentative organisms.

\section{Funding:}

This study was funded by the "Agence Nationale pour la Recherche Scientifique" (ANR-13BIME-0001).

\section{Conflict of Interest:}

The authors declare that they have no conflict of interest.

\section{Ethical approval:}

This article does not contain any studies with human participants or animals performed by any of the authors.

\section{References}

Adams MW (1990) The structure and mechanism of iron-hydrogenases. Biochim Biophys Acta 1020(2):115-45

Akhtar MK, Jones PR (2009) Construction of a synthetic YdbK-dependent pyruvate: $\mathrm{H}_{2}$ pathway in Escherichia coli BL21(DE3). Metab Eng 11(3):139-47 doi:10.1016/j.ymben.2009.01.002

Artz JH, Mulder DW, Ratzloff MW, Lubner CE, Zadvornyy OA, LeVan AX, Williams SG, Adams MWW, Jones AK, King PW, Peters JW (2017) Reduction Potentials of [FeFe]-Hydrogenase Accessory Iron-Sulfur Clusters Provide Insights into the Energetics of Proton Reduction Catalysis. J Am Chem Soc 139(28):9544-9550 doi:10.1021/jacs.7b02099

Avilan L, Roumezi B, Risoul V, Bernard CS, Kpebe A, Belhadjhassine M, Rousset M, Brugna M, Latifi A (2018) Phototrophic hydrogen production from a clostridial [FeFe] hydrogenase expressed in the heterocysts of the cyanobacterium Nostoc PCC 7120. Appl Microbiol Biotechnol 102(13):5775-5783 doi:10.1007/s00253-018-8989-2

Banu JR, Kannah RY, Kumar MD, Gunasekaran M, Sivagurunathan P, Park JH, Kumar G (2018) Recent advances on biogranules formation in dark hydrogen fermentation system: Mechanism of formation and microbial characteristics. Bioresour Technol 268:787-796 doi:10.1016/j.biortech.2018.07.034 
Bayer EA, Belaich JP, Shoham Y, Lamed R (2004) The cellulosomes: multienzyme machines for degradation of plant cell wall polysaccharides. Annu Rev Microbiol 58:521-54 doi:10.1146/annurev.micro.57.030502.091022

Benomar S, Ranava D, Cardenas ML, Trably E, Rafrafi Y, Ducret A, Hamelin J, Lojou E, Steyer JP, Giudici-Orticoni MT (2015) Nutritional stress induces exchange of cell material and energetic coupling between bacterial species. Nat Commun 6:6283 doi:10.1038/ncomms7283

Broderick JB, Byer AS, Duschene KS, Duffus BR, Betz JN, Shepard EM, Peters JW (2014) H-cluster assembly during maturation of the [FeFe]-hydrogenase. J Biol Inorg Chem 19(6):747-57 doi:10.1007/s00775-014-1168-8

Buckel W, Thauer RK (2013) Energy conservation via electron bifurcating ferredoxin reduction and proton/ $\mathrm{Na}\left({ }^{+}\right)$translocating ferredoxin oxidation. Biochim Biophys Acta 1827(2):94-113 doi:10.1016/j.bbabio.2012.07.002

Buckel W, Thauer RK (2018a) Flavin-Based Electron Bifurcation, A New Mechanism of Biological Energy Coupling. Chem Rev 118(7):3862-3886 doi:10.1021/acs.chemrev.7b00707

Buckel W, Thauer RK (2018b) Flavin-Based Electron Bifurcation, Ferredoxin, Flavodoxin, and Anaerobic Respiration With Protons (Ech) or $\mathrm{NAD}^{+}$(Rnf) as Electron Acceptors: A Historical Review. Front Microbiol 9:401 doi:10.3389/fmicb.2018.00401

Cai G, Jin B, Monis P, Saint C (2013) A genetic and metabolic approach to redirection of biochemical pathways of Clostridium butyricum for enhancing hydrogen production. Biotechnol Bioeng 110(1):338-42 doi:10.1002/bit.24596

Cai G, Jin B, Saint C, Monis P (2011) Genetic manipulation of butyrate formation pathways in Clostridium butyricum. J Biotechnol 155(3):269-74 doi:10.1016/j.jbiotec.2011.07.004

Calusinska M, Happe T, Joris B, Wilmotte A (2010) The surprising diversity of clostridial hydrogenases: a comparative genomic perspective. Microbiology 156(Pt 6):1575-88 doi:10.1099/mic.0.032771-0

Carere CR, Kalia V, Sparling R, Cicek N, Levin DB (2008) Pyruvate catabolism and hydrogen synthesis pathway genes of Clostridium thermocellum ATCC 27405. Indian J Microbiol 48(2):252-266 doi:10.1007/s12088-008-0036-z

Chandel AK, Chandrasekhar G, Silva MB, Silverio da Silva S (2012) The realm of cellulases in biorefinery development. Crit Rev Biotechnol 32(3):187-202 doi:10.3109/07388551.2011.595385

Cohen J, Kim K, King P, Seibert M, Schulten K (2005) Finding gas diffusion pathways in proteins: application to $\mathrm{O}_{2}$ and $\mathrm{H}_{2}$ transport in $\mathrm{Cpl}$ [FeFe]-hydrogenase and the role of packing defects. Structure 13(9):1321-9 doi:10.1016/j.str.2005.05.013

Das D, Veziroglu TN (2008) Advances in biological hydrogen production processes. Int J Hydrogen Energy 33:6046-6054

Demuez M, Cournac L, Guerrini O, Soucaille P, Girbal L (2007) Complete activity profile of Clostridium acetobutylicum [FeFe]-hydrogenase and kinetic parameters for endogenous redox partners. FEMS Microbiol Lett 275(1):113-21 doi:10.1111/j.1574-6968.2007.00868.x

Dubini A, Ghirardi ML (2015) Engineering photosynthetic organisms for the production of biohydrogen. Photosynth Res 123(3):241-53 doi:10.1007/s11120-014-9991-x

Ducat DC, Sachdeva G, Silver PA (2011) Rewiring hydrogenase-dependent redox circuits in cyanobacteria. Proc Natl Acad Sci U S A 108(10):3941-6 doi:10.1073/pnas.1016026108

Fontecilla-Camps JC, Volbeda A, Cavazza C, Nicolet Y (2007) Structure/function relationships of [NiFe]- and [FeFe]-hydrogenases. Chem Rev 107(10):4273-303 doi:10.1021/cr050195z

Frey M (2002) Hydrogenases: hydrogen-activating enzymes. Chembiochem 3(2-3):153-60

Gauquelin C, Baffert C, Richaud P, Kamionka E, Etienne E, Guieysse D, Girbal L, Fourmond V, Andre I, Guigliarelli B, Leger C, Soucaille P, Meynial-Salles I (2018) Roles of the F-domain in [FeFe] hydrogenase. Biochim Biophys Acta 1859(2):69-77 doi:10.1016/j.bbabio.2017.08.010

Greening C, Biswas A, Carere CR, Jackson CJ, Taylor MC, Stott MB, Cook GM, Morales SE (2016) Genomic and metagenomic surveys of hydrogenase distribution indicate $\mathrm{H}_{2}$ is a widely 
utilised energy source for microbial growth and survival. ISME J 10(3):761-77 doi:10.1038/ismej.2015.153

Gupta SK, Kumari S, Reddy K, Bux F (2013) Trends in biohydrogen production: major challenges and state-of-the-art developments. Environ Technol 34(13-16):1653-70 doi:10.1080/09593330.2013.822022

Hallenbeck PC (2005) Fundamentals of the fermentative production of hydrogen. Water Sci Technol 52(1-2):21-29

Hitit ZY, Lazaro CZ, Hallenbeck PC (2017) Hydrogen production by co-cultures of Clostridium butyricum and Rhodospeudomonas palustris: Optimization of yield using response surface methodology. Int J Hydrogen Energy 42:6578-6589

Hye JJ, Ok JC, Yoon LS, Sung LD, Moon PJ (2010) Molecular characterization and homologous overexpression of [FeFe]-hydrogenase in Clostridium tyrobutyricum JM1. Int J Hydrogen Energy 35:1065-1073

Jiang L, Wu Q, Xu Q, Zhu L, Huang $\mathrm{H}$ (2017) Fermentative hydrogen production from Jerusalem artichoke by Clostridium tyrobutyricum expressing exo-inulinase gene. Sci Rep 7(1):7940 doi:10.1038/s41598-017-07207-7

Joseph RC, Kim NM, Sandoval NR (2018) Recent Developments of the Synthetic Biology Toolkit for Clostridium. Front Microbiol 9:154 doi:10.3389/fmicb.2018.00154

Khanna N, Lindblad P (2015) Cyanobacterial hydrogenases and hydrogen metabolism revisited: recent progress and future prospects. Int J Mol Sci 16(5):10537-61 doi:10.3390/ijms160510537

Klein M, Ansorge-Schumacher MB, Fritscha M, Hartmeier M (2010) Influence of hydrogenase overexpression on hydrogen production of Clostridium acetobutylicum DSM 792. Enzyme Microb Technol 46(5):384-390

Koo J, Shiigi S, Rohovie M, Mehta K, Swartz JR (2016) Characterization of [FeFe] Hydrogenase $\mathrm{O}_{2}$ Sensitivity Using a New, Physiological Approach. J Biol Chem 291(41):21563-21570 doi:10.1074/jbc.M116.737122

Kothari R, Kumar V, Pathak VV, Ahmad S, Aoyi O, Tyagi VV (2017) A critical review on factors influencing fermentative hydrogen production. Front in Biosci 22:1195-1220

Kpebe A, Benvenuti M, Guendon C, Rebai A, Fernandez V, Le Laz S, Etienne E, Guigliarelli B, GarciaMolina G, de Lacey AL, Baffert C, Brugna M (2018) A new mechanistic model for an $\mathrm{O}_{2-}$ protected electron-bifurcating hydrogenase, Hnd from Desulfovibrio fructosovorans. Biochim Biophys Acta in Press

Kubas A, Orain C, De Sancho D, Saujet L, Sensi M, Gauquelin C, Meynial-Salles I, Soucaille P, Bottin H, Baffert C, Fourmond V, Best RB, Blumberger J, Leger C (2017) Mechanism of $\mathrm{O}_{2}$ diffusion and reduction in FeFe hydrogenases. Nat Chem 9(1):88-95 doi:10.1038/nchem.2592

Kumar G, Mudhoo A, Sivagurunathan P, Nagarajan D, Ghimire A, Lay CH, Lin CY, Lee DJ, Chang JS (2016) Recent insights into the cell immobilization technology applied for dark fermentative hydrogen production. Bioresour Technol 219:725-737

Lacasse MJ, Zamble DB (2016) [NiFe]-Hydrogenase Maturation. Biochemistry 55(12):1689-701 doi:10.1021/acs.biochem.5b01328

Lee SF, Forsberg CW, Gibbins LN (1985) Cellulolytic Activity of Clostridium acetobutylicum. Appl Environ Microbiol 50(2):220-8

Leroux F, Dementin S, Burlat B, Cournac L, Volbeda A, Champ S, Martin L, Guigliarelli B, Bertrand P, Fontecilla-Camps J, Rousset M, Leger C (2008) Experimental approaches to kinetics of gas diffusion in hydrogenase. Proc Natl Acad Sci U S A 105(32):11188-93 doi:10.1073/pnas.0803689105

Levin DB, Islam R, Cicek N, Sparling R (2006) Hydrogen production by Clostridium thermocellum 27405 from cellulosic biomass substrates. Int J Hydrogen Energy 31:1496-1503

Li F, Hinderberger J, Seedorf H, Zhang J, Buckel W, Thauer RK (2008) Coupled ferredoxin and crotonyl coenzyme A (CoA) reduction with NADH catalyzed by the butyryl-CoA dehydrogenase/Etf complex from Clostridium kluyveri. J Bacteriol 190(3):843-50 doi:10.1128/JB.01417-07 
Liu X, Zhu Y, Yang ST (2006) Construction and characterization of ack deleted mutant of Clostridium tyrobutyricum for enhanced butyric acid and hydrogen production. Biotechnol Prog 22(5):1265-75 doi:10.1021/bp060082g

Lo Y, Chen C, Lee C, Chang JS (2010) Sequential dark-photo fermentation and autotrophic microalgal growth for high-yield and $\mathrm{CO}_{2}$-free biohydrogen production. Int J Hydrogen Energy 35:10944 $-10953$

Martin BA, Frymier PD (2017) A Review of Hydrogen Production by Photosynthetic Organisms Using Whole-Cell and Cell-Free Systems. Appl Biochem Biotechnol 183(2):503-519 doi:10.1007/s12010-017-2576-3

Mitchell WJ (2016) Sugar uptake by the solventogenic clostridia. World J Microbiol Biotechnol 32(2):32

Mizuno O, Dinsdale R, Hawkes FR, Hawkes DL, Noike T (2000) Enhancement of hydrogen production from glucose by nitrogen gas sparging. Bioresour Technol 73:59-65

Montet Y, Amara P, Volbeda A, Vernede X, Hatchikian EC, Field MJ, Frey M, Fontecilla-Camps JC (1997) Gas access to the active site of Ni-Fe hydrogenases probed by X-ray crystallography and molecular dynamics. Nat Struct Biol 4(7):523-6

Morimoto K, Kimura T, Sakka K, Ohmiya K (2005) Overexpression of a hydrogenase gene in Clostridium paraputrificum to enhance hydrogen gas production. FEMS Microbiol Lett 246(2):229-34 doi:10.1016/j.femsle.2005.04.014

Nakayama S, Kosaka T, Hirakawa H, Matsuura K, Yoshino S, Furukawa K (2008) Metabolic engineering for solvent productivity by downregulation of the hydrogenase gene cluster hupCBA in Clostridium saccharoperbutylacetonicum strain N1-4. Appl Microbiol Biotechnol 78(3):483-93 doi:10.1007/s00253-007-1323-z

Nicolet Y, Piras C, Legrand P, Hatchikian CE, Fontecilla-Camps JC (1999) Desulfovibrio desulfuricans iron hydrogenase: the structure shows unusual coordination to an active site Fe binuclear center. Structure 7(1):13-23

Nomura T, Naimen A, Toyoda S, Kuriyama Y, Tokumoto H, Konishi Y (2014) Isolation and characterization of a novel hydrogen-producing strain Clostridium sp. suitable for immobilization. Int J Hydrogen Energy 39:1280-1287

Noth J, Kositzki R, Klein K, Winkler M, Haumann M, Happe T (2015) Lyophilization protects [FeFe]hydrogenases against $\mathrm{O}_{2}$-induced $\mathrm{H}$-cluster degradation. Sci Rep 5:13978 doi:10.1038/srep13978

Olson DG, McBride JE, Shaw AJ, Lynd LR (2012) Recent progress in consolidated bioprocessing. Curr Opin Biotechnol 23(3):396-405 doi:10.1016/j.copbio.2011.11.026

Orain C, Saujet L, Gauquelin C, Soucaille P, Meynial-Salles I, Baffert C, Fourmond V, Bottin H, Leger C (2015) Electrochemical Measurements of the Kinetics of Inhibition of Two FeFe Hydrogenases by $\mathrm{O}_{2}$ Demonstrate That the Reaction Is Partly Reversible. J Am Chem Soc 137(39):12580-7 doi:10.1021/jacs.5b06934

Ozgur E, Mars AE, Peksel B, Louwerse A, Yucel M, Gunduz U, Claassen PAM, Eroglu I (2010) Biohydrogen production from beet molasses by sequential dark and photo-fermentation. Int J Hydrogen Energy 35:511-517

Peters JW, Lanzilotta WN, Lemon BJ, Seefeldt LC (1998) X-ray crystal structure of the Fe-only hydrogenase ( $\mathrm{Cpl}$ ) from Clostridium pasteurianum to 1.8 angstrom resolution. Science 282(5395):1853-8

Peters JW, Schut GJ, Boyd ES, Mulder DW, Shepard EM, Broderick JB, King PW, Adams MW (2015) [FeFe]- and [NiFe]-hydrogenase diversity, mechanism, and maturation. Biochim Biophys Acta 1853(6):1350-69 doi:10.1016/j.bbamcr.2014.11.021

Plummer SM, Plummer MA, Merkel PA, Hagen M, Biddle JF, Waidner LA (2016) Using directed evolution to improve hydrogen production in chimeric hydrogenases from Clostridia species. Enzyme Microb Technol 93-94:132-141 doi:10.1016/j.enzmictec.2016.07.011

Poudel S, Tokmina-Lukaszewska M, Colman DR, Refai M, Schut GJ, King PW, Maness PC, Adams MW, Peters JW, Bothner B, Boyd ES (2016) Unification of [FeFe]-hydrogenases into three 
structural and functional groups. Biochim Biophys Acta 1860(9):1910-21 doi:10.1016/j.bbagen.2016.05.034

Rittmann S, Herwig C (2012) A comprehensive and quantitative review of dark fermentative biohydrogen production. Microb Cell Fact 11:115 doi:10.1186/1475-2859-11-115

Rotta C, Poehlein A, Schwarz K, McClure P, Daniel R, Minton NP (2015) Closed Genome Sequence of Clostridium pasteurianum ATCC 6013. Genome Announc 3(1) doi:10.1128/genomeA.0159614

Sabathe F, Belaich A, Soucaille P (2002) Characterization of the cellulolytic complex (cellulosome) of Clostridium acetobutylicum. FEMS Microbiol Lett 217(1):15-22

Schuchmann K, Muller V (2012) A bacterial electron-bifurcating hydrogenase. J Biol Chem 287(37):31165-71 doi:10.1074/jbc.M112.395038

Schut GJ, Adams MW (2009) The iron-hydrogenase of Thermotoga maritima utilizes ferredoxin and NADH synergistically: a new perspective on anaerobic hydrogen production. J Bacteriol 191(13):4451-7 doi:10.1128/JB.01582-08

Schwartz E, Fritsch J, Friedrich B (2013) $\mathrm{H}_{2}$-metabolizing prokaryotes. In: Rosenberg E, DeLong EF, Lory S, Stackebrandt E, Thompson F (eds) The Prokaryotes: Prokaryotic Physiology and Biochemistry. $4^{\text {th }}$ edn. Springer, Berlin, pp 119-199

Seelert T, Ghosh D, Yargeau V (2015) Improving biohydrogen production using Clostridium beijerinckii immobilized with magnetite nanoparticles. Appl Microbiol and Biotechnol 99(9):4107-16 doi:10.1007/s00253-015-6484-6

Shepard EM, Mus F, Betz JN, Byer AS, Duffus BR, Peters JW, Broderick JB (2014) [FeFe]-hydrogenase maturation. Biochemistry 53(25):4090-104 doi:10.1021/bi500210x

Show KY, Zhang ZP, Lee DJ (2008) Design of bioreactors for biohydrogen production. J Sci Ind Res 67:941-949.

Tangney M, Mitchell WJ (2007) Characterisation of a glucose phosphotransferase system in Clostridium acetobutylicum ATCC 824. Appl Microbiol Biotechnol 74(2):398-405 doi:10.1007/s00253-006-0679-9

Thauer RK, Jungermann K, Decker K (1977) Energy conservation in chemotrophic anaerobic bacteria. Bacteriol Rev 41(1):100-80

Therien JB, Artz JH, Poudel S, Hamilton TL, Liu Z, Noone SM, Adams MWW, King PW, Bryant DA, Boyd ES, Peters JW (2017) The Physiological Functions and Structural Determinants of Catalytic Bias in the [FeFe]-Hydrogenases $\mathrm{Cpl}$ and $\mathrm{Cpll}$ of Clostridium pasteurianum Strain W5. Front Microbiol 8:1305 doi:10.3389/fmicb.2017.01305

Thomas L, Joseph A, Gottumukkala LD (2014) Xylanase and cellulase systems of Clostridium sp.: an insight on molecular approaches for strain improvement. Bioresour Technol 158:343-50 doi:10.1016/j.biortech.2014.01.140

Vardar-Schara G, Maeda T, Wood TK (2008) Metabolically engineered bacteria for producing hydrogen via fermentation. Microb Biotechnol 1(2):107-25 doi:10.1111/j.17517915.2007.00009.x

Verhaart MR, Bielen AA, van der Oost J, Stams AJ, Kengen SW (2010) Hydrogen production by hyperthermophilic and extremely thermophilic bacteria and archaea: mechanisms for reductant disposal. Environ Technol 31(8-9):993-1003

Vignais PM, Billoud B (2007) Occurrence, classification, and biological function of hydrogenases: an overview. Chem Rev 107(10):4206-72 doi:10.1021/cr050196r

Vignais PM, Billoud B, Meyer J (2001) Classification and phylogeny of hydrogenases. FEMS Microbiol Rev 25(4):455-501

Wang S, Huang H, Kahnt J, Mueller AP, Kopke M, Thauer RK (2013a) NADP-specific electronbifurcating [FeFe]-hydrogenase in a functional complex with formate dehydrogenase in Clostridium autoethanogenum grown on CO. J Bacteriol 195(19):4373-86 doi:10.1128/JB.00678-13 
Wang S, Huang H, Kahnt J, Thauer RK (2013b) A reversible electron-bifurcating ferredoxin- and NADdependent [FeFe]-hydrogenase (HydABC) in Moorella thermoacetica. J Bacteriol 195(6):126775 doi:10.1128/JB.02158-12

Xiong W, Reyes LH, Michener WE, Maness PC, Chou KJ (2018) Engineering cellulolytic bacterium Clostridium thermocellum to co-ferment cellulose- and hemicellulose-derived sugars simultaneously. Biotechnol Bioeng 115(7):1755-1763 doi:10.1002/bit.26590

Yokoi H, Saitsu A, Uchida H, Hirose J, Hayashi S, Takasaki Y (2001) Microbial hydrogen production from sweet potato starch residue. J Biosci Bioeng 91(1):58-63

Zhao X, Xing D, Fu N, Liu B, Ren N (2011) Hydrogen production by the newly isolated Clostridium beijerinckii RZF-1108. Bioresour Technol 102(18):8432-6 doi:10.1016/j.biortech.2011.02.086

Zheng Y, Kahnt J, Kwon IH, Mackie RI, Thauer RK (2014) Hydrogen formation and its regulation in Ruminococcus albus: involvement of an electron-bifurcating [FeFe]-hydrogenase, of a nonelectron-bifurcating [FeFe]-hydrogenase, and of a putative hydrogen-sensing [FeFe]hydrogenase. J Bacteriol 196(22):3840-52 doi:10.1128/JB.02070-14 


\begin{tabular}{|c|c|c|c|}
\hline Microorganism & Feeding substrate and process & $\begin{array}{l}\text { Yield of } \mathrm{H}_{2} \\
\text { production } \\
\text { (mol/mol } \\
\text { glucose) }\end{array}$ & Ref \\
\hline Clostridium beijerinckii & $\begin{array}{l}\text { Glucose } \\
\text { Free suspension }\end{array}$ & 1.97 & $\begin{array}{c}\text { Zhao et al. } \\
2011\end{array}$ \\
\hline Clostridium sp. & $\begin{array}{l}\text { Glucose } \\
\text { Cells immobilized in polyethylene } \\
\text { glycol- } b \text {-polypropylene glycol }\end{array}$ & 2.91 & $\begin{array}{l}\text { Nomura } \\
\text { et al. } 2014\end{array}$ \\
\hline Clostridium beijerinckii & $\begin{array}{l}\text { Glucose } \\
\text { Cells immobilized in Alginate- } \\
\text { chitosan-magnetite nanoparticle }\end{array}$ & 2.1 & $\begin{array}{l}\text { Seelert et } \\
\text { al. } 2015\end{array}$ \\
\hline $\begin{array}{c}\text { Clostridium butyricum } \\
\text { Co-culture with Enterobacter } \\
\text { aerogenes }\end{array}$ & $\begin{array}{l}\text { Potato starch waste } \\
\text { medium/peptone } \\
\text { Free suspension }\end{array}$ & 2.4 & $\begin{array}{l}\text { Yokoi et } \\
\text { al. } 2001\end{array}$ \\
\hline $\begin{array}{c}\text { Clostridium acetobutylicum } \\
\text { Co-culture with Desulfovibrio } \\
\text { vulgaris }\end{array}$ & $\begin{array}{l}\text { Glucose } \\
\text { Free suspension }\end{array}$ & 3.4 & $\begin{array}{l}\text { Benomar } \\
\text { et al. } 2015\end{array}$ \\
\hline $\begin{array}{c}\text { Clostridium butyricum } \\
\text { Sequential culture with } \\
\text { Rhodopseudomonas palustris }\end{array}$ & $\begin{array}{l}\text { Sucrose } \\
\text { Free suspension }\end{array}$ & 5.81 & $\begin{array}{l}\text { Lo et } \\
\text { al.2010 }\end{array}$ \\
\hline $\begin{array}{c}\text { Clostridium butyricum } \\
\text { Co-culture with } \\
\text { Rhodopseudomonas palustris }\end{array}$ & $\begin{array}{l}\text { Potato juice/glucose } \\
\text { Free suspension }\end{array}$ & 6.4 & $\begin{array}{l}\text { Hitit et al. } \\
2017\end{array}$ \\
\hline $\begin{array}{c}\text { Clostridium butyricum } \\
\text { Co-culture with Enterobacter } \\
\text { aerogenes } \\
\text { Sequential culture with } \\
\text { Rhodobacter sp. }\end{array}$ & $\begin{array}{l}\text { Potato starch waste } \\
\text { medium/peptone } \\
\text { Free suspension }\end{array}$ & 7.2 & $\begin{array}{l}\text { Yokoi et } \\
\text { al. } 2001\end{array}$ \\
\hline
\end{tabular}

609

610

611

Legend to Figure 1: Schematic representation of dark fermentation in Clostridia.

$\mathrm{H}_{2}$ is produced by a monomeric $\mathrm{FeFe}-\mathrm{H}_{2}$ ase using ferredoxin ( $\mathrm{Fd}$ ) or by a bifurcating $\mathrm{H}_{2}$ ase using both Fd and NADH. Electron transfer from NADH to Fd is indicated in dashed arrow.

Competitive pathways are indicated.

Possible lines of future research on $\mathrm{H}_{2}$-production enhancement are indicated by colored dots.

Red dots stand for the improvement of waste and agricultural residue degradation and sugar uptake. Improvement of the biochemical and structural features of $\mathrm{H}_{2}$ ases is indicated by blue dots. Yellow dots point to the possibility of inhibiting competitive pathways in order to rewire 
619 larger amounts of reductants to $\mathrm{H}_{2}$ production. PTS: phosphotransferase sugar transport 620 system.

621 
$622 \quad$ Figure 1

623

Schematic representation of dark fermentation in Clostridia

Substrates

Metabolic

Products pathways

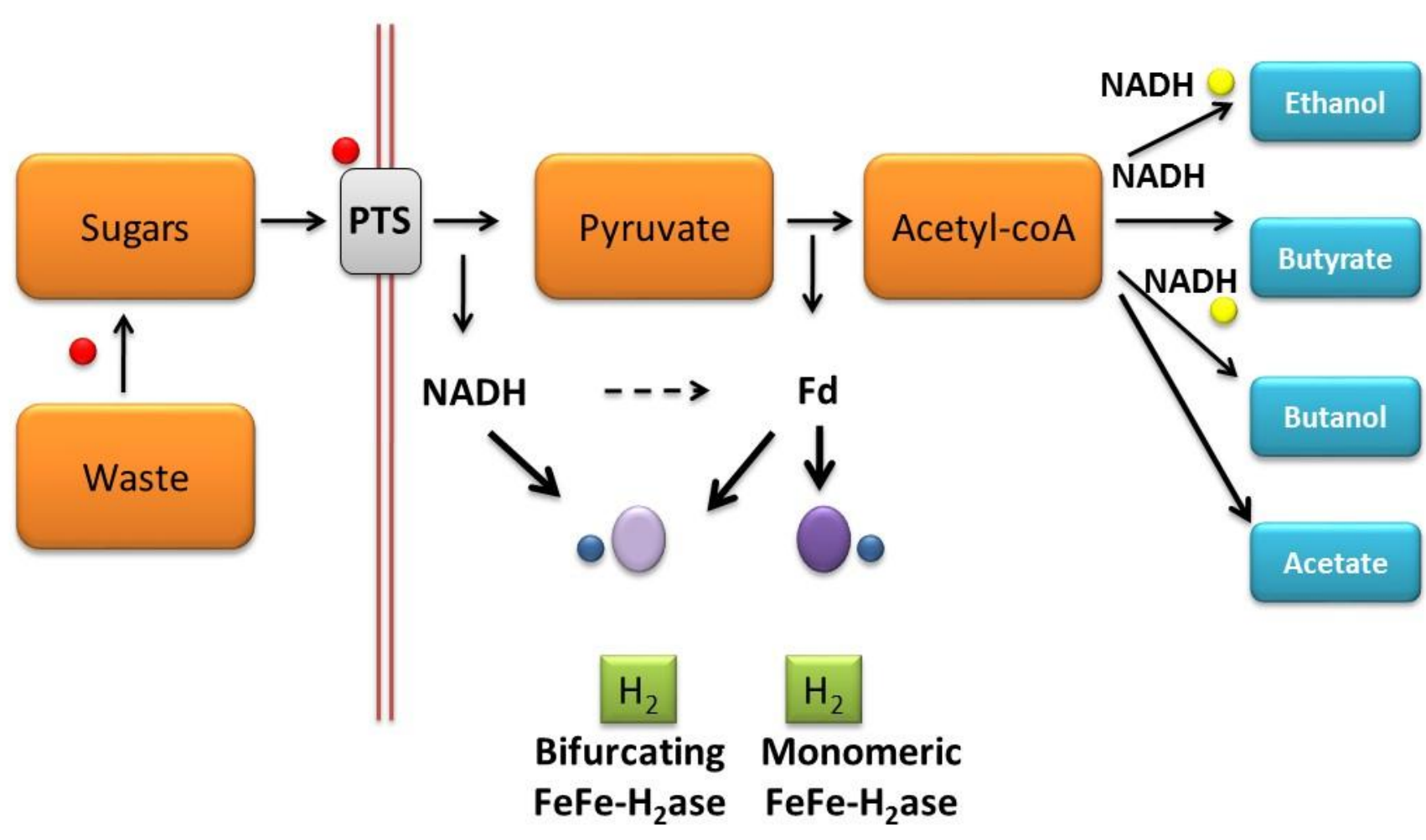

